\title{
Audit Plan, Audit Program Dan Audit Prosedur Pada Harta, Utang Dan Modal
}

\author{
Novianty \\ Noviantynovi1611@gmail.com, Jurusan Akuntansi, Universitas Widya Dharma Pontianak
}

\begin{abstract}
ABSTRAK
Manfaat penelitian ini adalah untuk mengetahui bagaimana proses dan prosedur audit plan, audit program dan audit prosedur pada harta, utang dan modal. Penelitian ini juga diharapkan dapat memberikan kontribusi bagi perusahaan untuk mengetahui apakah persediaan dievaluasi oleh manajemen perusahaan setiap waktu dan bagaimana cara melakukan audit pada sistem persediaan di tengah maraknya sistem online telah banyak digunakan saat ini. Metode penelitian yang digunakan dalam penelitian ini adalah metode analisis deskriptif yang dilakukan dengan membahas semua materi ataupun teori Audit Plan, Audit Program Dan Audit Prosedur Pada Harta, Utang Dan Modal dengan berpedoman pada standar dan prosedur audit yang berlaku. Hasil penelitian ini menunjukkan bahwa para auditor dan akuntan publik harus melakukan survey pendahuluan terlebih dahulu mengenai data atau identitas perusahaan yang akan diauditnya sebelum melakukan audit plan, audit program dan audit prosedur. Audit plan, audit program dan audit prosedur harus dipersiapkan dan dilakukan sebaik mungkin agar menghasilkan kualitas audit yang baik sehingga pada akhirnya akan menghasilkan laporan audit yang baik juga.
\end{abstract}

Kata kunci: Audit Plan, Audit Program, Audit Prosedur, Harta, Utang dan Modal

\section{ABSTRACT}

The benefit of this research is to find out how the audit plan, audit program and audit procedures and procedures on assets, debt and capital are used. This research is also expected to be able to contribute to the company to find out whether inventory is being evaluated by company management at all times and how to audit the inventory system in the midst of the rise of online systems has been widely used today. The research method used in this research is a descriptive analysis method which is done by discussing all the material or theory of the Audit Plan, Program Audit and Audit Procedures on Assets, Debt and Capital by referring to the applicable audit standards and procedures. The results of this study indicate that auditors and public accountants must conduct a preliminary survey of the data or identity of the company to be audited before conducting an audit plan, program audit and audit procedures. Audit plan, program audit and audit procedures must be prepared and carried out as well as possible in order to produce a good audit quality so that in the end it will produce a good audit report as well.

Keyword: Audit Plan, Audit Program, Audit Prosedur, Aktiva, Liabilities and Common Stock

\section{PENDAHULUAN}

\section{Latar Belakang}

Dewasa ini, kebutuhan akan audit plan, audit program dan audit prosedur yang efisien, efektif dan ekonomis terhadap aktiva, utang dan modal semakin diperlukan mengingat makin maraknya fraud atau kecurangan yang menjadi tantangan berat bagi para auditor maupun akuntan publik. Dengan adanya penyusunan audit plan, audit program dan audit prosedur 
diharapkan auditor dapat menghasilkan kualitas audit yang baik. Apabila auditor memiliki kualitas audit yang baik, maka auditor dapat merekomendasikan sistem pengawasan intern yang baik bagi perusahaan-perusahaan langganannya sehingga dapat meningkatkan image auditor tersebut. Peningkatan image akan berpengaruh pada peningkatan jumlah pelanggan bagi auditor tersebut sehingga mampu memberikan kontribusi dan kepuasan bagi para pelanggannya.

Salah satu konsep yang perlu diperhatikan dalam audit plan, audit program maupun audit prosedur adalah konsep mengenai harta, utang dan modal karena komponen-komponen tersebut merupakan komponen pada Laporan posisi keuangan yang dapat mencerminkan posisi keuangan suatu perusahaan. Rekayasa dan kecurangan rawan terjadi pada komponen harta, utang dan modal sehingga perlu adanya pemeriksaan atau review secara teliti oleh para auditor. Oleh karena itu, para auditor harus menyusun audit plan, audit program dan audit prosedur terhadap komponen harta, utang dan modal secara baik. Kombinasi audit plan, audit program dan audit prosedur yang baik akan membantu manajemen perusahaan mencapai visi dan misi perusahaan serta dapat menghindarkan perusahaan dari resiko kerugian.

Pentingnya penelitian ini dilakukan agar manajemen perusahaan dapat memahami secara jelas alur audit plan, audit program dan audit prosedur pada harta, utang dan modal pada perusahaan sehingga diharapkan dapat meminimalkan fraud yang terjadi dalam perusahaan. Penelitian ini juga diharapkan dapat memberikan kontribusi bagi perusahaan untuk mengetahui apakah persediaan dievaluasi oleh manajemen perusahaan setiap waktu dan bagaimana cara melakukan audit pada sistem persediaan di tengah maraknya sistem online telah banyak digunakan saat ini.

\section{TINJAUAN PUSTAKA \\ Pengertian Audit Plan}

Standar Pekerjaan Lapangan I : "Pekerjaan harus direncanakan sebaik-baiknya dan jika digunakan asisten harus disupervisi dengan semestinya. (Agoes : 99). Berdasarkan kutipan di atas, dapat diketahui bahwa sebelum menjalankan program audit dan menyusun prosedur audit, maka para auditor harus menyusun audit plan yang baik.

Menurut Boynton et al (2006:284) menyatakan bahwa "perencanaan audit atau audit plan melibatkan pengembangan suatu strategi menyeluruh untuk pelaksanaan dan penentuan lingkup audit yang diharapkan. Auditor harus merencanakan audit dengan suatu sikap skeptisme profesional mengenai hal-hal seperti integritas manajemen, kekeliruan dan ketidakberesan, serta tindakan melawan hukum."

Jumlah perencanaan yang diperlukan dalam suatu perikatan akan bervariasi menurut ukuran dan kompleksitas klien, pengetahuan auditor serta pengalaman dengan klien. Pengawasan melibatkan pengarahan asisten dalam tim audit yang berpartisipasi untuk mencapai tujuan audit dan menentukan bahwa tujuan telah dicapai. Di antara faktor-faktor lainnya, luasnya pengawasan yang diperlukan dalam suatu perikatan bergantung pada kualifikasi orang-orang yang melaksanakan pekerjaan. Oleh karena itu, dalam merencanakan audit, harus dibuat provisi untuk pengawasan yang lebih banyak apabila beberapa anggota tim audit tidak berpengalaman daripada jika mereka telah berpengalaman.

\section{Pengertian Audit Program}

Setelah audit plan disusun dan sebelum pemeriksaan lapangan dimulai, auditor harus menyusun audit program yang merupakan kumpulan dari prosedur audit yang akan dijalankan dan dibuat secara tertulis. Audit program membantu auditor dalam memberikan perintah kepada asisten mengenai pekerjaan yang harus dilaksanakan. (Agoes:104). 
Menurut Arens and Loebbecke, program audit dirancang dalam 3 bagian yaitu pengujian atas transaksi, prosedur analitis dan pengujian terinci atas saldo. (Arens and Loebbecke : 319).

Menurut Sawyer et al (2005:205), program audit dirancang untuk menjadi pedoman bagi auditor mengenai:

1. Apa yang akan dilakukan

2. Kapan akan dilakukan

3. Siapa yang akan melakukannya

4. Berapa lama waktu yang dibutuhkan

Berdasarkan uraian di atas, maka dapat disimpulkan bahwa program audit merupakan alat yang menghubungkan survei pendahuluan dengan pekerjaan lapangan. Dalam survei pendahuluan, auditor mengidentifikasi tujuan operasi, risiko, kondisi-kondisi operasi dan kontrol yang diterapkan.

Adapun beberapa manfaat audit program menurut Sawyer et al (2005: 206) adalah:

1. Memberikan rencana sistematis untuk setiap tahap pekerjaan audit yang merupakan suatu rencana yang dapat dikomunikasikan baik kepada supervisor audit maupun kepada staf audit.

2. Menjadi dasar penugasan auditor.

3. Menjadi sarana pengawasan dan evaluasi kemajuan pekerjaan audit karena memuat waktu audit yang dianggarkan.

4. Memungkinkan supervisor audit dan manajer membandingkan apa yang dikerjakan dengan apa yang direncanakan.

5. Membantu melatih staf-staf yang belum berpengalaman dalam tahap-tahap pelaksanaan audit.

6. Memberi ringkasan catatan pekerjaan yang dilakukan.

7. Membantu auditor pada audit selanjutnya untuk mengenal lebih dekat jenis-jenis pekerjaan audit yang dilakukan dan waktu yang dibutuhkan.

8. Mengurangi waktu supervisi langsung yang dibutuhkan.

9. Menjadi titik awal bagi penilai fungsi audit internal untuk mengevaluasi upaya audit yang telah dilakukan.

\section{Pengertian Audit Prosedur}

Menurut Sawyer et al (2005:212), audit prosedur adalah "Teknik-teknik yang diterapkan auditor untuk menentukan apakah tujuan operasi telah dicapai."

Menurut Boynton et al (2006:236), prosedur audit adalah "Metode atau teknik yang digunakan oleh para auditor untuk mengumpulkan dan mengevaluasi bahan bukti yang mecukupi dan kompeten."

Audit prosedur dilakukan dalam rangka mendapatkan bahan-bahan bukti (audit evidence) yang cukup untuk mendukung pendapat auditor atas kewajaran laporan keuangan.

Auditor yang profesional biasanya memiliki latar belakang yang memungkinkan pembedaan antara tujuan audit yang harus dicapai dalam mengevaluasi suatu masalah dan mana yang tidak relevan atau tidak penting dalam pencapaian tujuan. Oleh karena itu, program audit harus dirancang untuk menjadi pedoman auditor mengenai prosedur audit apa yang akan dilakukan untuk mencapai tujuan-tujuan audit. Pengalaman dan logika auditor juga akan menentukan prosedur-prosedur audit mana yang akan sesuai untuk tujuan audit. Prosedur harus relevan dengan tujuan-tujuan yang telah dipilih. Prosedur-prosedur yang tidak relevan akan sia-sia jika tidak menghasilkan bahan bukti yang sesuai dengan penelaahan pencapaian tujuan operasi.

Berikut ini sepuluh jenis prosedur audit yang dirumuskan oleh Boynton et al (2006:237) yaitu: 
1. Prosedur analitis (analytical procedures)

2. Inspeksi (inspecting)

3. Konfirmasi (confirming)

4. Permintaan keterangan (inquiring)

5. Penghitungan (counting)

6. Penelusuran (tracing)

7. Pemeriksaan bukti pendukung (vouching)

8. Pengamatan (observing)

9. Pelaksanaan ulang (reperforming)

10. Teknik audit berbantuan komputer (computer-assisted audit techniques)

\section{Audit Plan, Audit Program dan Audit Prosedur Atas Persediaan}

Salah satu komponen pada harta atau aktiva yang perlu mendapatkan perhatian serius dari para auditor yang akan melaksanakan audit plan, audit program dan audit prosedur adalah persediaan karena nilainya yang cenderung besar atau material. Ada beberapa faktor yang dapat mempengaruhi kerumitan audit persediaan yaitu:

a. Persediaan umumnya merupakan komponen utama dalam Laporan posisi keuangan yang memiliki nilai yang material

b. Persediaan dapat tersebar di beberapa lokasi yang menyulitkan

c. Pengendalian fisik dan penghitungannya

d. Persediaan umumnya memiliki jenis yang sangat beragam dan kuantitas yang banyak

e. Persediaan dapat mencakup bahan baku (raw material), bahan penolong (indirect material), barang dalam proses (work in process) dan barang jadi (finished goods).

f. Penilaian persediaan memiliki tingkat kesulitan yang tinggi karena faktor umur persediaan dan alokasi biaya pabrikasi.

g. Adanya kewajiban menerapkan metode penilaian persediaan secara konsisten.

Dalam paragraf 3 SA Seksi 331 (PSA No. 07) menyatakan bahwa jika kuantitas persediaan hanya ditentukan melalui penghitungan fisik dan semua penghitungan dilakukan pada tanggal Laporan posisi keuangan atau pada suatu tanggal dalam periode yang tepat, baik sebelum maupun sesudah tanggal Laporan posisi keuangan, maka auditor perlu hadir pada saat penghitungan fisik persediaan.

\section{METODE PENELITIAN \\ Desain Penelitian}

Metode penelitian yang digunakan dalam penelitian ini adalah metode analisis deskriptif yang dilakukan dengan membahas cakupan materi ataupun teori mengenai Audit Plan, Audit Program Dan Audit Prosedur Pada Harta, Utang Dan Modal dengan berpedoman pada standar dan prosedur audit yang berlaku. Pembahasan cakupan materi maupun teori dimaksudkan untuk meningkatkan pemahaman dan wawasan mengenai konsep teori Audit Plan, Audit Program Dan Audit Prosedur Pada Harta, Utang Dan Modal.

\section{HASIL PENELITIAN DAN PEMBAHASAN}

Audit plan, audit program dan audit prosedur harus diperhatikan oleh para auditor sebelum melakukan kegiatan audit. Jika hal tersebut tidak mendapatkan perhatian, maka akan menimbulkan masalah yang dapat merugikan auditor. Salah satu contoh kasus yang terjadi yaitu Kantor Akuntan Publik Biasa Sitepu. Menurut harian Kompas.com yang dimuat pada tanggal 18 Mei 2020, Kantor Akuntan Publik Biasa Sitepu menjadi tersangka kasus korupsi pinjaman kredit perusahaan otomotif Raden Motor kepada BRI pada 2009 senilai Rp 52 miliar pada tanggal 11 Juni 2010. Kasus tersebut terjadi karena kantor akuntan publik Biasa Sitepu tidak melakukan survey pendahuluan maupun tahapan-tahapan audit seperti audit plan, 
audit program dan audit prosedur sebelum menjalankan proses audit pada Raden Motor sehingga laporan audit yang dihasilkan oleh kantor akuntan publik Biasa Sitepu menyesatkan banyak orang.

\section{Tahapan Audit Plan Pada Harta, Utang dan Modal}

Ada beberapa prosedur dalam melakukan audit plan pada kas, utang dan modal yaitu:

a. Menyusun internal control yang baik atas Kas dan Bank serta transaksi penerimaan dan pengeluaran Kas dan Bank berupa:

1. Adanya pemisahan tugas dan tanggungjawab antara yang menerima dan mengeluarkan kas dengan yang melakukan pencatatan, memberikan otorisasi atas pengeluaran dan penerimaan Kas dan Bank.

2. Pegawai yang membuat Rekonsiliasi Bank harus lain dari pegawai yang mengerjakan buku Bank. Rekonsiliasi Bank dibuat setiap bulan dan harus ditelaah (di-review) oleh Kepala Bagian Akuntansi.

3. Digunakannya imprest fund system untuk mengelola kas kecil.

4. Penerimaan kas, check dan giro, harus disetor ke bank dalam jumlah seutuhnya (intact) paling lambat keesok harinya.

b. Menyusun internal control yang baik atas utang dan modal yaitu dengan melakukan konfirmasi kepada pihak bank maupun supplier untuk memastikan saldo pada posisi utang maupun modal.

c. Merencanakan strategi audit dengan mempertimbangkan semua risiko buruk yang akan terjadi yang dapat mengganggu posisi harta, utang dan modal.

Ada beberapa langkah dalam melakukan audit plan pada kas, utang dan modal yaitu:

a. Memeriksa apakah terdapat internal control yang cukup baik atas Kas dan Bank serta transaksi penerimaan dan pengeluaran Kas dan Bank. Jika akuntan publik (auditor) dapat meyakinkan dirinya bahwa internal control atas Kas dan Bank serta transaksi penerimaan dan pengeluaran Kas dan Bank berjalan efektif, maka luasnya pemeriksaan dalam melakukan substantive test bisa dipersempit. Beberapa ciri internal control yang baik atas Kas dan Bank serta transaksi penerimaan dan pengeluaran Kas dan Bank adalah :

a) Adanya pemisahan tugas dan tanggung jawab antara yang menerima dan mengeluarkan kas dengan yang melakukan pencatatan, memberikan otorisasi atas pengeluaran dan penerimaan Kas dan Bank.

b) Pegawai yang membuat Rekonsiliasi Bank harus lain dari pegawai yang mengerjakan buku Bank. Rekonsiliasi Bank dibuat setiap bulan dan harus ditelaah (di-review) oleh Kepala Bagian Akuntansi .

c) Digunakannya imprest fund system untuk mengelola kas kecil.

d) Penerimaan kas, check dan giro, harus disetor ke bank dalam jumlah seutuhnya (intact) paling lambat keesok harinya.

e) Uang kas harus disimpan ditempat yang aman, misalnya di cash box, brandkast, atau di bank.

f) Uang kas harus dikelola dengan baik, dalam arti jangan dibiarkan menganggur atau terlalu banyak disimpan di rekening giro, karena tidak memberikan hasil yang optimal. Jika ada uang kas yang menggangur sebaiknya disimpan dalam deposito berjangka atau dibelikan surat berharga yang sewaktu-waktu bisa diuangkan (marketable), sehingga bisa menghasilkan bunga atau dividen.

g) Blanko check dan giro harus disimpan ditempat yang aman supaya tidak disalahgunakan, selain itu harus dihindari penandatanganan check dalam bentuk blanko. Pada saat penandatanganan check, harus dilampirkan bukti-bukti pendukung yang lengkap. 
h) Sebaiknya cek dan giro ditulis atas nama dan check/giro ditandatangani oleh 2 orang untuk menghindari penyalahgunaan.

i) Sebaiknya kasir diasuransikan atau diminta menyerahkan uang jaminan, untuk backup seandainya terjadi kehilangan uang atau kecurangan yang dilakukan oleh kasir.

j) Digunakannya kwitansi yang bernomor urut tercetak (prenumbered).

k) Bukti-bukti pendukung dari pengeluaran kas yang sudah dibayar harus di stempel lunas, untuk menghindari kemungkinan untuk di proses pembayarannya dua kali (double payment).

b. Memeriksa apakah saldo Kas dan Bank yang ada di Laporan posisi keuangan per tanggal Laporan posisi keuangan betul-betul ada dan dimiliki perusahaan. Maksudnya auditor harus menyakini dirinya bahwa kas yang dimiliki perusahaan (on Hand dan in Bank) betul-betul ada dan dimiliki perusahaan dan bukan milik pribadi direksi atau pemegang saham. Karena itu auditor harus melakukan cash opname dan mengirim konfirmasi bank.

c. Untuk memeriksa apakah ada pembatasan untuk penggunaan saldo Kas dan Bank. Jika perusahaan menyisihkan sebagian dana yang dimiliki untuk keperlukan pelunasan obligasi berikut bunganya (sinking fund) maka dana tersebut tidak dapat dilaporkan sebagai bagian dari kas di harta lancar. Begitu juga jika ada saldo rekening giro yang dibekukan karena perusahaan tersangkut suatu masalah hukum, maka saldo tersebut tidak boleh dilaporkan sebagai bagian dari kas di harta lancar.Hal tersebut harus dijelaskan dalam Catatan Atas Laporan Keuangan.

d. Untuk memeriksa seandainya ada saldo Kas dan Bank dalam valuta asing, apakah saldo tersebut sudah dikonversikan ke dalam rupiah dengan menggunakan kurs tengah Bank Indonesia (BI) pada tanngal Laporan posisi keuangan dan apakah selisih kurs yang terjadi sudah dibebankan atau dikreditkan ke Laporan Laba-Rugi tahun berjalan. Misalnya : Per 31 Desember 2004 perusahaan mempunyai saldo bank sebesar US \$100.000 yang di buku besar dicatat dalam rupiah sebesar Rp 910.000.000. Kurs BI per 31 Desember 2004: Kurs jual US \$1 Rp. 9.160, dan kurs beli US \$1 = Rp. 9.140. Maka saldo US \$ 100.000 tersebut harus dikonversikan ke dalam rupiah dengan menggunakan Kurs US $\$ 1=$ Rp. 9.150. karena itu harus dibuat adjustment :
i. Dr Bank
Rp.5.000.000
ii. Cr Laba Selisih Kurs
Rp.5.000.000

(Untuk mengoreksi selisih kurs dari saldo bank dalam US \$ per tanggal Laporan posisi keuangan)

e. Memeriksa apakah penyajian Kas \& Bank di Laporan posisi keuangan sesuai dengan prinsip akuntansi yang berlaku umum.

Menurut SAK : Kas dan Bank disajikan di Laporan posisi keuangan sebagai harta lancar (Current Assets). Kas dan Bank yang penggunaannya dibatasi dapat dimasukkan dalam aktiva lancar harta jika pembatasan tersebut dilakukan untuk menyisihkan dana untuk melunasi kewajiban jangka pendek atau jika pembatasan tersebut hanya berlaku selama satu tahun. Saldo kredit pada perkiraan bank disajikan pada kelompok kewajiban sebagai kewajiban jangka pendek. Saldo kredit dan debit rekening giro pada bank yang sama dapat digabungkan dan disajikan pada Laporan posisi keuangan sebagai satu kesatuan.

Penulis setuju terhadap perumusan audit plan karena audit plan merupakan konsep awal yang perlu mendapatkan perhatian serius dari auditor sebelum melakukan kegiatan audit untuk menghasilkan laporan audit yang baik. Ada tiga alasan utama mengapa auditor harus merencanakan tugasnya dengan sebaik-baiknya, yakni untuk memperoleh bahan bukti kompeten yang cukup dalam situasi saat itu, untuk membantu menekan biaya audit, untuk menghindari salah pengertian dengan klien. 
Dalam perencanaan auditnya, auditor harus mempertimbangkan sifat, lingkup, dan pada saat pekerjaan harus dilaksanakan yaitu membuat suatu program audit secara tertulis (satu set program audit tertulis) untuk setiap audit. Program audit harus menggariskan dengan rinci prosedur audit yang menurut keyakinan auditor diperlukan untuk mencapai tujuan audit. Bentuk program audit dan tingkat kerinciannya sangat bervariasi sesuai dengan keadaan. Selama berlangsungnya audit, perubahan kondisi dapat menyebabkan terjadinya perubahan prosedur audit yang telah direncanakan tersebut.

\section{Tahapan Audit Program Pada Kas, Utang dan Modal}

Ada beberapa langkah dalam melakukan audit program pada kas, utang dan modal yaitu

1. Auditor harus melakukan compliance test (pengujian ketaatan), namun sebelumnya perlu disusun audit program untuk pengujian ketaatan atas transaksi penerimaan dan pengeluaran Kas \& Bank sebagai berikut :

\section{Audit Program Penerimaan Kas dan Bank}

a) Ambil sampel bukti penerimaan Kas dan Bank secara random : semua penerimaan kas yang berjumlah > Rp. 10 Juta ditambah 10 penerimaan Kas \& Bank yang berjumlah $<$ Rp.10 juta.

b) Periksa apakah bukti penerimaan kas tersebut :

a. Sudah diotorisasi pejabat perusahaan yang berwenang.

b. Lengkap bukti pendukungnya (misalnya kwitansi bernomor urut tercetak, deposito slip)

c. Mencantumkan nomor perkiraan yang dikredit dengan benar dan perhitungan mathematisnya sudah benar.

c) Periksa apakah posting ke buku besar penjualan (untuk penjualan tunai) dan piutang (untuk pelunasan piutang) sudah dilakukan dengan benar.Begitu juga untuk posting ke sub buku besar piutang.

d) Tarik kesimpulan mengenai hasil compliance test.

\section{Audit Program Pengeluaran Kas dan Bank}

1. Ambil sampel bukti pengeluaran Kas dan Bank secara random : semua pengeluaran kas yang berjumlah $>$ Rp.5 juta ditambah 10 pengeluaran Kas \& Bank yang berjumlah <Rp.5 juta.

2. Periksa apakah bukti pengeluaran kas tersebut :

a) Sudah diotorisasi pejabat perusahaan yang berwenang.

b) Lengkap bukti pendukungnya (misalnya PR, PO, supplier invoice, RR, kwitansi dari supplier dan lain-lain).

c) Mencantumkan nomor perkiraan yang di debit dengan benar.

d) Perhitungan matematiknya sudah benar.

3. Periksa apakah posting ke buku besar dan sub buku besar (misalnya hutang) sudah dilakukan dengan benar.

4. Tarik kesimpulan mengenai hasil compliance test.

1. Buat Top schedule Kas dan Bank pertanggal Laporan posisi keuangan.

2. Lakukan cash count.

Jika klien menggunakan imprest fund system untuk kas kecilnya, cash count bisa dilakukan kapan saja karena saldo kas selalu tetap. Tetapi jika digunakan fluctuanting fund system, maka cash count sebaiknya dilakukan tidak jauh dari tanggal Laporan posisi keuangan agar tidak mengalami kesulitan sewaktu melakukan perhitungan maju atau mundur ke tanggal Laporan posisi keuangan 
(saldo kas pertanggal cash count ditambah atau dikurangi dengan penerimaan atau/dan pengeluaran sebelum/sesudah tanggal Laporan posisi keuangan).

3. Kirim konfirmasi atau dapatkan pernyataan saldo dari akhir dalam hal tidak dilakukan kas opname.

Untuk Kas yang berada di cabang yang jauh dan saldonya tidak besar (misalnya di Papua dengan saldo Rp 5.000.000) tidak perlu auditor khusus mengunjungi cabang tersebut untuk melakukan kas opname karena tidak berimbang cost and benefitnya. Dalam hal ini cukup kirim surat konfirmasi atau diminta pernyataan saldo dari kasir.

5. Kirim konfirmasi untuk seluruh rekening bank yang dimiliki perusahaan.

Surat konfirmasi tersebut harus ditandatangani oleh pejabat perusahaan yang nama dan contoh tandatangannya tercantum di "signature card" bank perusahaan (authorized signature). Konfirmasi tersebut bisa mencantumkan nomor rekening bank perusahan tetapi akan lebih baik jika nomor rekening tersebut tidak dicantumkan.

Surat konfirmasi harus tetap dikirm walaupun perusahan sudah menerima rekening koran dari bank karena :

1) Hal tersebut merupakan standard audit procedures untuk mendapatkan bahan pembuktian (audit evidence).

2) Yang ditanyakan dalam surat konfirmasi bukan hanya saldo bank tetapi banyak hal lainnya, seperti : jumlah kredit, pendiskontoan wesel tagih, contingent liability dan lain-lain.

3) Jawaban konfirmasi diminta untuk dikirm langsung ke auditor, sedangkan rekening koran selalu dikirim ke klien.

6. Minta rekonsiliasi bank dan dapat lakukan pemeriksaan atas rekonsiliasi bank tersebut.

Rekonsilisi bank harus dibuat oleh klien dan tugas auditor adalah memeriksa kebenaran rekonsiliasi tersebut, serta mengusulkan audit adjustment jika ditemukan suatu kesalahan.

Audit program yang biasa dilakukan adalah :

1. Cocokkan saldo menurut rekening koran bank dengan rekening koran bank yang bersangkutan dan jawaban konfirmasi bank.

2. Periksa footing dan cross footing.

3. Cocokkan saldo menurut pembukuan dengan saldo buku Kas \& Bank dan buku besar Kas \& Bank.

4. Periksa outstanding check dan outstanding deposit ke rekening koran bulan berikutnya, perhatikan apakah ada check yang outstanding lebih dari 70 hari sehingga perlu dibuatkan jurnal koreksi.

5. Periksa biaya administrasi bank dan jasa giro ke rekening koran dan nota debit/kredit.

Tahapan Pengauditan antara lain :

1. Review jawaban konfirmasi dari bank, notulen rapat dan perjanjian kredit untuk mengetahui apakah ada pembatasan dari rekening bank yang dimiliki perusahaan.

Saldo rekening bank yang penggunaannya dibatasi untuk jangka waktu > 1 tahun tidak boleh di kelompokkan sebagai harta lancar dan harus dijelaskan di catatan atas laporan keuangan mengenai alasan pembatasan tersebut. Pembatasan tersebut bisa terjadi karena perusahaan mempunyai masalah hukum sehingga rekeningnya dibekukan atau karena dijadikan jaminan, bank garansi (sebagai dari saldonya). 
Untuk mengetahui apakah ada pembatasan atau tidak, auditor bisa menanyakan kepada klien, mereview jawaban konfirmasi bank, notulen rapat dan perjanjian kredit. Kemungkinan juga ada saldo Kas \& Bank yang merupakan "sinking fund"sehingga tidak boleh digunakan untuk membiayai kegiatan rutin perusahaan, karena dana itu akan digunakan untuk pelunasan obligasi atau expansi perusahaan.

2. Periksa interbank transfer $+/-1$ minggu sebelum dan sesudah tanggal Laporan posisi keuangan, untuk mengetahui adanya kitting dengan tujuan untuk window dressing.

Check kitting bisa dilakukan jika perusahaan mempunyai lebih dari satu rekening bank. Misalnya PT. A mempunyai rekening di Bank BRI cabang Petojo Jakarta, dan di BANK MANDIRI Ambon. Misalnya tanggal 29 Desember ditransfer dari BANK MANDIRI Ambon sebesar Rp. 50.000.000 ke Bank BRI Petojo, jumlah sebesar Rp. 50.000.000 sudah dicatat sebagai penambahaan saldo di rekening Bank BRI Petojo, tetapi belum dikurangi dari saldo BANK MANDIRI Ambon. Akibatnya saldo Kas \& Bank di Laporan posisi keuangan akan terlihat lebih besar Rp.50.000.000, sehingga current ratio PT.A akan terlihat lebih baik, (terjadi window dressing -melaporkan sesuatu lebih baik dari keadaan yang sebenarnya).

Untuk mengetahui ada tidaknya check kitting, auditor harus memeriksa transfer dari rekening bank perusahaan ke rekening bank perusahaan yang lain dan mencocokkan apakah penambahan saldo di rekening bank yang berasal dari transfer sudah diikuti dengan pengurangan saldo di rekening bank lainnya. Karena, biasanya check kitting dilakukan mendekati tanggal Laporan posisi keuangan, maka periode yang harus diperiksa +/- 1 minggu sebelum dan sesudah tanggal Laporan posisi keuangan.

3. Periksa transaksi kas sesudah tanggal Laporan posisi keuangan (subsequent payment dan subsequent collection) sampai mendekati tanggal selesainya pemeriksaan lapangan.

Tujuannya adalah untuk mengetahui apakah ada unrecorded liabilities (kewajiban yang belum tercatat) per tanggal Laporan posisi keuangan yang baru dibayar di periode berikutnya, baik yang berasal dari pembelian asset ataupun biayabiaya perusahaan. Misalnya di Januari 2008 ditemukan adanya pembayaran ke penasehat hukum perusahaan untuk konsultasi bulan Desember 2007 yang belum di accrued per 31 Desember 2007.

Tujuan lainnya untuk mengetahui apakah utang pertanggal Laporan posisi keuangan sudah dilunasi diperiode berikutnya, sehingga auditor lebih yakin mengenai kewajaran saldo Utang pertanggal Laporan posisi keuangan. Untuk subsequent collection, tujuannya terutama untuk menyakinkan auditor mengenai kewajaran angka Piutang pertanggal Laporan posisi keuangan. Mungkin saja ada penjualan, misalnya Desember 2007, yang dilunasi Januari 2008 dan belum dicatat oleh perusahaan.

4. Seandainya ada saldo Kas dan Bank dalam mata uang asing pertanggal Laporan posisi keuangan, periksa apakah saldo tersebut sudah dikonversikan ke dalam rupiah dengan menggunakan kurs tengah BI pada tanggal Laporan posisi keuangan, dan apakah selisih kurs yang terjadi sudah dibebankan atau dikreditkan pada Laporan Laba-Rugi tahun berjalan.

Kurs tengah BI adalah rata-rata kurs beli dan kurs jual di Bank Indonesia yang bisa di lihat di surat kabar atau bussiness news. Misalnya per tanggal 31 Desember 2004 perusahaan mempunyai piutang ke XYZ Corporation di Hongkong sebesar US \$ 50.000 yang tercatat di buku perusahaan sebesar Rp.450.000.000 (kurs tanggal pencatatan US \$1 = Rp. 9.000). Per 31 Desember 2004 kurs tengah BI adalah Rp. 9.100 per US $\$ 1$, untuk itu harus dibuat adjusment sebagai berikut : 
Dr Piutang Rp. 5.000 .000

$\mathrm{Cr} \quad$ Laba selisih kurs Rp. 5.000 .000

5. Periksa apakah penyajian Kas dan Bank di Laporan posisi keuangan dan catatan atas laporan keuangan, sesuai dengan prinsip akuntansi yang berlaku umum (SAK).

\section{Penyajian di Laporan posisi keuangan :}

Pada umumnya Kas dan Bank merupakan harta lancar, saldo deposito berjangka tidak boleh dilaporkan sebagai bagian dari Kas dan Bank, jika ada saldo bank bersaldo kredit dengan jumlah yang material, harus direklasifikasi sebagai Utang jangka pendek.

\section{PT.ABC}

\section{Laporan posisi keuangan}

31-12-2009 dan 2010

\begin{tabular}{|c|c|c|}
\hline & $\underline{31-12-2010}$ & $\underline{31-12-2009}$ \\
\hline \multicolumn{3}{|l|}{ Kas dan Bank } \\
\hline Note 3 & Rp.75.000.000 & Rp.50.000.000 \\
\hline \multicolumn{3}{|l|}{ Piutang } \\
\hline \multicolumn{3}{|l|}{ Persedian,dst } \\
\hline \multicolumn{3}{|c|}{ Di Catatan atas Laporan Keuangan : } \\
\hline \multicolumn{3}{|c|}{ Note 3 : Saldo Kas dan Bank per 31 Desember 2007 dan 2006 terdiri dar } \\
\hline & $\underline{31-12-2010}$ & $\underline{31-12-2009}$ \\
\hline Petty cash Jakarta & $\overline{\text { Rp. } 1.000 .000}$ & $\overline{\text { Rp. } 1.000 .000}$ \\
\hline Petty Cash Surabaya & Rp. 3.000 .000 & Rp. 2.000 .000 \\
\hline Bank BRI 46 Jakarta & Rp. 50.000 .000 & Rp.20.000.000 \\
\hline Bank BRI 46 Surabaya & $\underline{\text { Rp. } 21.000 .000}$ & $\underline{\text { Rp. } 17.000 .000}$ \\
\hline Jumlah & $\overline{\mathrm{Rp.75.000.000}}$ & $\overline{\mathbf{R p . 5 0 . 0 0 0 . 0 0 0}}$ \\
\hline
\end{tabular}

\section{Catatan :}

Perbedaan jurnal entry antara imprest fund system dan fluctuating fund system dalam pengelolaan kas kecil adalah sebagai berikut :

\section{Imprest Fund}

\section{Fluctuating Fund}

6. Pengadaan Petty Cash
Dr. Petty Cash
$\mathrm{xx}$
$\mathrm{xx}$
Dr. Petty cash
$\mathrm{XX}$
$\mathrm{Cr} \quad$ Cash in Bank
$\mathrm{Cr} \quad$ Cash in Bank
$\mathrm{XX}$

7. Penyaluran kas kecil untuk membayar biaya rutin

No Entry

Dr Biaya Telepon $\mathrm{xx}$

Dr Biaya transport $\mathrm{xx}$

$\mathrm{Cr} \quad$ Petty cash $\quad \mathrm{xx}$

8. Penerimaan Uang dari hasil penjualan tunai

No Entry

Dr Petty cash Xx

$\mathrm{Cr} \quad$ Sales $\mathrm{xx}$ 
9. Pengisian kembali petty cash dengan membuka cek
Dr Biaya-biaya
$\mathrm{Cr} \quad$ Cash in bank
$\mathrm{xx}$
Dr Petty cash
$\mathrm{xx}$
$\mathrm{XX}$
$\mathrm{Cr} \quad$ Cash in Bank
$\mathrm{XX}$

Penulis berpendapat bahwa audit program perlu dilakukan agar menghasilkan laporan audit yang baik sehingga dapat menghindarkan perusahaan dari resiko kecurangan.

\section{Tahapan Audit Prosedur Pada Harta, Utang Dan Modal}

Ada beberapa langkah dalam melakukan audit prosedur pada kas, utang dan modal yaitu:

1. Pahami dan evaluasi internal control atas Kas dan Bank serta transaksi penerimaan dan pengeluaran Kas dan Bank.

2. Buat Top Schedule Cash on Hand and in Bank pertanggal Laporan posisi keuangan (misal per 31-12-2007) atau kalau belum selesai, boleh 31-10-2007 atau 30-11-2007: penambahan mutasi akan diperiksa kemudian, apakah ada hal-hal yang unusual (di luar kebiasaan) atau tidak.

3. Lakukan cash count (perhitungan phisik uang kas) per tanggal Laporan posisi keuangan, bisa juga sebelum atau sesudah tanggal Laporan posisi keuangan.

4. Kirim komfirmasi atau dapatkan pernyataan saldo dari kasir dalam hal tidak dilakukan kas opname.

5. Kirim konfirmasi untuk seluruh rekening bank yang dimilik perusahaan.

6. Minta rekonsiliasi bank per tanggal Laporan posisi keuangan (misalnya per 31-122007), kalau terpaksa karena belum selesai yang Desember, dapat diminta per 31-112007.

7. Lakukan pemeriksaan atas rekonsiliasi bank tersebut.

8. Review jawaban konfirmasi dari bank, notulen rapat dan perjanjian kredit untuk mengetahui apakah ada pembatasan dari rekening bank yang dimilik perusahaan.

9. Periksa inter bank transfer +- 1 minggu sebelum dan sesudah tanggal nerca, untuk mengetahui adanya kitting dengan tujuan untuk window dressing.

10. Periksa transaksi kas sesudah tanggal Laporan posisi keuangan (subsequent payment dan subsequent collection) sampai mendekakati tanggal selesainya pemeriksaan lapangan.

11. Seandainya ada saldo Kas dan Bank mata uang asing pertanggal Laporan posisi keuangan, periksa apakah salso tersebut sudah dikonversikan ke dalam rupiah dengan menggunakan kurs tengah BI pada tanggal Laporan posisi keuangan dan apakah selisih kurs yang terjadi sudah dibebankan atau dikreditkan pada rugi dan laba tahun berjalan.

12. Periksa apakah penyajian Kas dan Bank di Laporan posisi keuangan dan Catatan Atas Laporan Keuangan, sesuai dengan prinsip akuntansi yang berlaku sebelumnya.

13. Buat kesimpulan di Top Schedule Kas dan Bank atau di memo tersendiri mengenai kewajaran dari cah on hand dan in bank, setelah kita menjalankan seluruh audit prosedur di atas.

\section{Penjelasan Prosedur Pemeriksaan Kas dan Bank}

Pahami dan evaluasi internal control atas Kas dan Bank serta transaksi penerimaan dan pengeluaran Kas dan Bank. Proses memahami dan mengevaluasi internal control atas Kas dan Bank serta penerimaan dan pengeluaran Kas dan Bank merupakan bagian yang sangat penting dalam suatu proses pemeriksaan akuntan. Kas dan bank dalam perusahaan sering dikatakan sebagai darah dalam tubuh manusia. 
Sebagai contoh berikut ini adalah suatu prosedur audit untuk pengujian transaksi pengeluaran kas.

Ambilah buku jurnal pengeluaran kas dan bandingkanlah nama sipembayar, nilai uang, dan tanggal pada berbagai cek yang ditangguhkan dengan data yang terdapat dalam buku jurnal pengeluaran kas.

\section{Ukuran Sampel}

Setelah memilih prosedur audit, mungkin sekali memilih beragam ukuran sampel dari hanya satu sampel hingga semua item yang terdapat dalam populasi yang sedang di uji. Dalam prosedur audit yang telah dibahas diatas, anggaplah bahwa terdapat 6.600 cek yang tercatat dalam buku jurnal pengeluaran kas. Auditor barangkali akan memilih ukuran sampel sebesar 50 cek sebagai perbandingan dengan buku jurnal pengeluaran kas. Keputusan untuk memilih seberapa banyak item yang akan diuji haruslah dibuat oleh auditor untuk masing-masing prosedur audit yang ada. Ukuran sampel bagi setiap prosedur tersebut kemungkinan besar akan berbeda antara satu penugasan audit dengan penugasan audit lainnya.

\section{Item-item yang terpilih}

Setelah menentukan ukuran sampel untuk prosedur audit dilakukan, haruslah ditentukan item-item mana dari populasi yang akan diuji. Jika auditor memutuskan, umpamanya, untuk memilih 50 cek yang ditangguhkan dari populasi sebesar 6.600 cek sebagai item-item yang akan dibandingkan dengan data pada buku jurnal pengeluaran kas, maka dapat digunakan berbagai metode yang berbeda untuk emmilih cek-cek manakah yang akan di uji. Auditor dapat (1) memilih 50 cek pertama yang tercatat dalam periode 1 minggu, (2) memilih 50 cek bernilai terbesar, (3) memilih cek-cek tersebut secara acak, atau, (4) memilih cek-cek yang menurut auditor memiliki kemungkinan kandungan kekeliruan yang besar.

\section{Pemilihan Waktu yang tepat}

Audit atas laporan keuangan umumnya mencakup periode waktu tertentu seperti satu tahun, pada umumnya proses audit baru selesai dilaksanakan setelah beberapa minggu atau beberapa bulan setelah berakhirnya suatu periode waktu. Waktu pelaksanaan berbagai prosedur audit beragam mulai dari awal suatu periode akuntansi atau lama setelah periode akuntansi itu berakhir.

Berbagai prosedur audit seringkali menggabungkan antara ukuran sampel, item-item yang diuji, dan pemilihan waktu yang tepat kedalam prosedur audit. Berikut ini adalah suatu modifikasi dari prosedur audit diatas yang mencamtumkan keempat keputusan-keputusan bukti audit.

Ambilah buku jurnal pengeluaran kas bulan oktober dan bandingkanlah nama si pembayar, nilai uang dan tanggal pada berbagai cek yang ditangguhkan dengan data yang terdapat dalam buku jurnal pengeluaran kas tersebut untuk suatu sampel yang dipilih secara acak atas 40 nomor cek.

Jika perusahaan mengalami kesulitan uang, sama seperti manusia yang "lesu darah" atau "kekurangan darah". Selain itu hampir semua transaksi perusahaan menyangkut Kas dan Bank.

Hasil evaluasi internal control atas Kas dan Bank serta transaksi penerimaan dan pengeluaran Kas dan Bank berupa kesimpulan apakah internal control efektif, berarti luasnya pengujian atas kewajaran saldo Kas dan Bank pertanggal Laporan posisi keuangan bisa dipersempit, karena kemungkinan terjadinya kesalahan adalah kecil dan jika kesalahan terjadi akan bisa segera ditemukan oleh pihak perusahaan. Untuk 
memahami internal control yang terdapatdi perusahaan,auditor bisa melakukan tanya jawab dengan klien dengan menggunakan internal control questionnaires. Kemudian hasil tanya jawab digambarkan lebih lanjut dalam flowchart dan (jika dianggap perlu) dalam bentuk cerita (narrative).

Berdasarkan jawaban ICQ, flowchart dan penjelasan narrative (jika ada), auditor bisa mengevaluasi internal control yand ada secara teoritis dan menarik kesimpulan sementara apakah internal control atas Kas dan Bank serta penerimaan dan pengeluaran Kas \& Bank baik, sedang atau lemah. Jika kesimpulan test ketaatan atas transaksi penerimaan dan pengeluaran Kas \& Bank, untuk membuktikan apakah internal control berjalan efektif atau tidak.

Yang diambil sebagai sample biasanya bukti penerimaan Kas \& Bank dan bukti pengeluaran Kas \& Bank atau nomor check/giro. Jika kesimpulan sementara bahwa internal control lemah, auditor tidak perlu mengadakan test ketaatan, tetapi langsung melakukan substantive test yang diperluas. Karena biasanya jika tetap dilakukan compliance test, kesimpulan akhir tetap menyatakan bahwa internal control lemah.

Setelah compliance test selesai dilakukan, auditor harus menarik kesimpulan akhir apakah internal control baik, sedang, atau lemah. Setelah itu baru dilakukan substantive test atas saldo Kas \& Bank. Audit prosedur untuk compliance test harus dipisahkan dari audit prosedur untuk substantive test, begitu juga kertas kerja pemeriksaannya.

Hasil tanya jawab dengan klien mengenai prosedur penerimaan Kas dan Bank, didokumentasikan oleh auditor dalam bentuk narrative. Berdasarkan penjelasan narrative, flowchart dan jawaban internal control questionnaires atas sistem dan prosedur penerimaan dan pengeluaran Kas \& Bank pada PT. RENIKU, misalnya ditarik kesimpulan sementara bahwa pengendalian intern atas penerimaan dan penegluaran Kas \& Bank cukup baik dan tidak diidentifikasikan suatu risiko kesalahan yang material.

Penulis berpendapat bahwa audit prosedur pada perusahaan harus dirumuskan dengan baik oleh auditor dan dijalankan oleh semua pihak pada perusahaan sehingga menghasilkan internal control maupun kualitas audit yang baik.

\section{Tahapan Audit Pada Persediaan}

Menurut Weber (1999, pp.11-13), tujuan dari audit sistem informasi adalah: Meningkatkan Perlindungan Terhadap Aset Perusahaan, Meningkatkan Integritas Data, Meningkatkan Efektifitas Sistem dan Meningkatkan Efisiensi Sistem.

Gondodiyoto dan Idris (2003, hh.155-158) berpendapat bahwa ada tiga metode audit sistem informasi antara lain:

\section{Audit Around the Computer}

Untuk menerapkan metode ini, auditor pertama kali harus menelusuri dan menguji pengendalian masukan, kemudian menghitung hasil yang diperkirakan dari proses transaksi, lalu auditor membandingkan hasil sesungguhnya dengan hasil yang dihitung secara manual.

\section{Audit Through the Computer}

Pada metode ini, auditor tidak hanya melakukan pengujian pada input dan output melainkan juga pemeriksaan secara langsung terhadap pemrosesan komputer melalui pemeriksaan logika dan akurasi program meliputi koding program, desain aplikasi, serta hal lain yang berkaitan dengan program aplikasinya.

\section{Audit With the Computer}

Pada metode ini audit dilakukan dengan menggunakan komputer dan software untuk mengotomatisasi prosedur pelaksanaan audit. Metode ini sangat bermanfaat dalam pengujian substantif atas file dan record perusahaan. Salah satu software audit yang dapat 
digunakan adalah GAS (Generalized Audit Software) dan SAS (Specialized Audit Software). Tahapan audit sistem informasi adalah sebagai berikut:

1. Planning the Audit (Perencanaan Audit).

2. Tests of Control (Pengujian Pengendalian).

3. Tests of Transactions (Pengujian Transaksi).

4. Substantive Test (Pengujian Substantif).

5. Completion of the Audit (Penyelesaian Audit).

Penulis menyimpulkan bahwa sistem pengendalian internal adalah sistempengendaliandalam suatu organisasi yang dirancang untuk mencegah dan mendeteksi terhadap kesalahan yang akan terjadi serta mengendalikan dan melindungi seluruh aktivitas organisasi dari penyimpanganpenyimpangan lainnya yang dapat merugikan perusahaan. Sistem pengendalian internal memiliki empat tujuan utama, yaitu untuk: Mengamankan aktiva organisasi, Memastikan akurasi dan keandalan dari catatan dan informasi akuntansi, Mempromosikan efisiensi operasi perusahaan, Mengukur kesesuaian dengan kebijakan dan prosedur yang telah ditetapkan manajemen.

Prosedur barang masuk diawali oleh perusahaan dengan membuat nomor anggota dan pin anggota, setelah nomor anggota dan pin anggota selesai dibuat, bagian gudang mengirimkan nomor anggota dan pin tersebut ke percetakan (yang sudah menjalin kerja sama dengan Perusahaan) dan membuat Surat Permintaan Pencetakan.

Setelah Member Kit selesai, percetakan mengirimkan Member Kit tersebut dengan disertai Faktur serta Surat Jalan (SJ) masing-masing 3 rangkap. Faktur dan Surat Jalan asli diserahkan ke Bagian Gudang, faktur rangkap 2, 3 dan Surat Jalan rangkap 2, 3 untuk bagian percetakan. Setelah menerima dan melakukan pengecekan barang, bagian Gudang menandatangani Faktur serta Surat Jalan tersebut.

Berdasarkan Faktur dan Surat Jalan tersebut, Bagian Gudang membuat Bukti Penerimaan Barang (BPB) sebanyak 3 rangkap. BPB rangkap 1 untuk Percetakan, rangkap 2 diarsip oleh Bagian Gudang, $B P B$ rangkap 3 diserahkan kepada Bagian Akuntansi. Setelah dokumen BPB diotorisasi, Bagian Gudang mengisi Kartu Stock Manual untuk barang masuk serta membuat Laporan Barang Masuk untuk diserahkan ke Direktur.

Proses pengeluaran barang gudang dimulai ketika Bagian Penjualan menyerahkan Form Order (FO) yang berisi pesanan customer yang ingin membeli member kit ke bagian Gudang. Selanjutnya Bagian Gudang akan melakukan validasi order yaitu mengecek stock barang yang tersedia. Jika barang tersedia, Bagian Gudang menyiapkan barang serta mengkonfirmasikan ke Bagian Penjualan. Kemudian Bagian Penjualan membuat Faktur dan mengkonfirmasikan nomor Faktur ke Bagian Gudang untuk dibuatkan Surat Jalan (SJ) sebanyak 3 rangkap. SJ rangkap 1, 3 diserahkan ke Bagian Penjualan dan SJ rangkap 2 diarsip oleh Bagian Gudang. Kemudian Bagian Gudang menyerahkan barang beserta Surat Jalan tersebut ke Bagian Penjualan. Selanjutnya Bagian Gudang mengisi Kartu Stock Manual barang keluar. Laporan Persediaan diserahkan kepada Direktur Utama setiap akhir bulan.

Dokumen-dokumen yang digunakan pada sistem informasi persediaan perusahaan ini adalah:

1. Surat Permintaan Pencetakan Barang

Dokumen berupa surat yang berisi jenis dan jumlah barang yang dipesan oleh perusahaan untuk dicetak oleh bagian Percetakan. Dokumen surat ini dikirim melalui email ke bagian Percetakan.

2. Bukti Penerimaan Barang (BPB)

Suatu dokumen yang dikeluarkan oleh Bagian Gudang sebagai bukti bahwa barang yang dibeli perusahaan telah diterima oleh Gudang sebagaimana yang tercantum pada BPB (mencakup kondisi, kuantitas, dan jenisnya). Dokumen BPB ini juga 
merupakan dokumen sumber yang dijadikan dasar penginputan data barang masuk pada sistem informasi persediaan.

3. Kartu Stock Manual

Dokumen yang digunakan oleh Bagian Gudang untuk mencatat setiap perubahan data stock (barang keluar dan barang masuk) yang terjadi secara manual.

4. Form Order (FO)

Merupakan dokumen yang dikeluarkan oleh Bagian Penjualan sebagai permintaan barang keluar kepada Bagian Gudang. Dokumen ini juga digunakan sebagai dasar pembuatan Surat Jalan dan proses pengupdatean data stock pada kartu stock manual.

5. Surat Jalan

Dokumen yang dibuat oleh Bagian Gudang berdasarkan FO yang dikeluarkan oleh Bagian Penjualan sebagai tanda keluarnya barang gudang sekaligus sebagai dokumen sumber pengupdatean data barang keluar pada kartu stock manual.

Laporan yang dihasilkan dari sistem informasi persedian Perusahaan ini adalah:

1. Laporan Barang Masuk

Laporan ini merupakan laporan yang berisi seluruh item barang yang masuk ke dalam gudang.

2. Laporan Persediaan

Laporan ini berisi barang yang masuk dan barang yang keluar yang dibuat setiap bulan untuk diserahkan kepada Direktur.

Penulis memandang perancangan internal kontrol terhadap persediaan perlu dilakukan agar menghasilkan audit persediaan yng berkualitas sehingga menghindarkan terjadinya resiko penyelewengan ataupun kecurangan yang akan dilakukan oleh manajemen ataupun karyawan perusahaan.

\section{Audit Sistem Informasi Persediaan Perusahaan}

Proses audit ini terdiri dari beberapa tahap, yaitu: perencanaan dan program audit, instrumen pengumpulan bukti audit yang digunakan untuk setiap pengendalian, matriks penilaian resiko dan rekomendasi pengendalian berdasarkan standar yang ditetapkan serta menyajikan laporan audit. Auditor membatasi ruang lingkup auditnya sebagai berikut:

1. Audit yang dilakukan terhadap sistem informasi persediaan (member kit) yang dimulai dari proses barang masuk, proses pengeluaran barang serta proses pengupdatean data jumlah stock pada sistem informasi persediaan.

2. Pengendalian yang merupakan pembahasan penulis yang meliputi:

- Pengendalian Manajemen (Management Control):

Pengendalian Manajemen Keamanan (Security Management Controls) dan Pengendalian Manajemen Operasi (Operations Management Controls).

- Pengendalian aplikasi (Aplication control):

Pengendalian Boundary, Input, dan Output.

3. Metode audit yang digunakan dalam melakukan audit adalah dengan pendekatan Audit Arround the Computer.

4. Menyajikan laporan.

Tujuan audit sistem informasi persediaan sebagai berikut:

- Mengetahui pengendalian yang diterapkan oleh perusahaan dalam sistem informasi persediaannya.

- Mengidentifikasi kelemahan-kelemahan dari pengendalian yang diterapkan oleh perusahaan dalam sistem persediaannya.

- Melakukan audit terhadap pengendalian sistem informasi persediaan yang sedang berjalan. 
- Melakukan penilaian terhadap resiko berdasarkan kelemahan-kelemahan yang ditemukan pada pengendalian sistem informasi persediaannya.

- Membuat rekomendasi perbaikan berdasarkan kelemahan-kelemahan dan resiko yang ditemukan dari proses audit tersebut. Instrumen pengumpulan bukti audit yang digunakan: studi pustaka, wawancara, kuesioner, observasi, testing aplikasi.

Prosedur audit terhadap persediaan perlu mendapatkan perhatian serius dari manajemen perusahaan karena akan meminimalkan resiko terjadinya kecurangan terhadap persediaan. Salah satu kasus manipulasi persediaan yang diperoleh dari sumber Tempo.co tanggal 08 Desember 2003 yaitu kasus penggelembungan persediaan yang dilakukan oleh Direksi PT Kimia Farma, Tbk. pada tahun 2002 merupakan bukti bahwa prosedur audit harus dilakukan secara benar sehingga Kantor Akuntan Publik terhindar dari resiko kerugian. Pada kasus penggelembungan persediaan PT Kimia Farma, Tbk., auditor yang mengaudit PT Kimia Farma, Tbk. yaitu Hans Tuanakotta \& Mustofa (HTM) dikenakan sanksi denda senilai Rp 100 juta dikarenakan tidak mampu mengatasi resiko audit dan tidak mampu mendeteksi kecurangan yang dilakukan oleh Direksi PT Kimia Farma, Tbk.

Kecurangan biasanya ditemukan karena suatu ketidaksengajaan ataupun disengaja. Untuk mengatasi timbulnya kecurangan, audit internal diperlukan keberadaannya di dalam perusahaan, yang bertugas untuk mengevaluasi suatu sistem dan prosedur yang telah disusun secara benar dan sistematis serta apakah telah diimplementasikan secara benar, melalui pengamatan, penelitian, dan pemeriksaan atas pelaksanaan tugas yang telah didelegasikan di setiap unit kerja perusahaan.

\section{SIMPULAN}

Adapun kesimpulan dari penelitian ini adalah:

a. Para auditor dan akuntan publik harus melakukan survey pendahuluan terlebih dahulu mengenai data atau identitas perusahaan yang akan diauditnya sebelum melakukan audit plan, audit program dan audit prosedur.

b. Audit plan, audit program dan audit prosedur harus dipersiapkan dan dilakukan sebaik mungkin agar menghasilkan kualitas audit yang baik sehingga pada akhirnya akan menghasilkan laporan audit yang baik juga.

c. Audit (auditing) adalah suatu proses sistematis mendapatkan dan mengevaluasi buktibukti secara objektif sehubungan dengan asersi atas tindakan dan peristiwa ekonomi untuk memastikan tingkat kesesuaian antara asersi-asersi tersebut dan menetapkan kriteria serta mengomunikasikan hasilnya kepada pihak-pihak yang berkepentingan.

d. Kompetensi dan independensi menentukan kualitas audit. Dalam audit, terdapat istilah fraud (kecurangan) dan fraudulent financial reporting (kecurangan pelaporan keuangan) yang berkaitan dengan tindakan yang tidak baik dalam mengaudit laporan keuangan.

e. Auditor dan manajemen perusahaan harus bersama-sama meningkatkan perhatian pada tindakan pencegahan fraud sehingga visi dan misi perusahaan lebih mudah dicapai.

\section{REFERENSI}

Amin Widjaja, Tunggal, 2005, “Internal Auditing (Suatu Pengantar)”. Harvarindo. Jakarta.

Arens, A. Alvin dan James K. Loebbecke. 1996. Auditing : Pendekatan Terpadu. Salemba Empat. Jakarta.

Agoes, Sukrisno. 1996. Auditing : Pemeriksaan Akuntan. Edisi kedua. Jilid I. Lembaga Penerbit Fakultas Ekonomi Universitas. Jakarta. 
Agoes, Sukrisno. 1996. Auditing : Pemeriksaan Akuntan. Edisi kedua. Jilid II. Lembaga Penerbit Fakultas Ekonomi Universitas. Jakarta.

Agoes, Sukrisno. 2012. Petunjuk Praktis Pemeriksaan Akuntan oleh Akuntan Publik. Salemba Empat, Jakarta.

Agoes, Sukrisno. 2016. Auditing : Petunjuk Praktis Pemeriksaan Akuntan oleh Akuntan Publik. Edisi empat. Salemba Empat, Jakarta.

Agoes, Sukrisno. 2018. Auditing : Petunjuk Praktis Pemeriksaan Akuntan oleh Akuntan Publik. Edisi kedua. Salemba Empat, Jakarta.

Boynton, William C., Johnson, Raymond . 2006. Modern Auditing: Assurance Services and The Integrity of Financial Reporting, 8th ed. United States of Amerika: John Wiley \& Sons, Inc.

Hery, 2017. Auditing dan Asurans. Grasindo, Jakarta.

Ikatan Akuntan Indonesia, 1994. Standar Profesional Akuntan Publik, STIE YKPN. Yogyakarta.

Institut Akuntan Publik Indonesia. 2011. Standar Profesional Akuntan Publik 31 Maret 2011. Diperbanyak oleh Salemba Empat, Jakarta.

Jusuf, Amir Abadi. 1996. Auditing : Pendekatan Terpadu. Salemba Empat. Jakarta.

Kalbers, Lawrence P. Dan Fogarty, Timothi J. 1995. "profesionalism and its Consequences: A Study of Internal Auditors", Auditing: A Journal of Practice and theory, 14: 64-86. Ohio.

Messier, F. William,. Glover, M.Steven, and Prawit, F. Douglas. 2014. Jasa Audit dan Assurance. Salemba Empat, Jakarta.

Rahayu, Siti Kurnia dan Ely Suhayati. 2010. Auditing : Konsep Dasar dan Pedoman Pemeriksaan Akuntan Publik. Graha Ilmu. Yogyakarta.

Sawyer, B. Lawrence, Mortimur A. Dittenhofer dan James H. Scheiner. 2005. Sawyer's Internal Auditing: Audit Internal Sawyer. Salemba Empat. Jakarta.

Sawyer, B. Lawrence, Dittenhofer Mortimer A, Scheiner James H, 2009. Internal Auditing, Diterjemahkan oleh:DesiAdhariani, Jilid 1, Edisi 5, Salemba Empat. Jakarta.

Sawyer, B. Lawrence et al. 2012. Internal Auditing Sawyers, 6th edition. Institute of Internal Auditors. Florida.

Weber, Ron. 1999. Information Systems Control and Audit. Prentice Hall.

William, C. Boynton, Raymond N. Johnson dan Walter G. Kell. 2002. Modern Auditing. Erlangga. Jakarta. 